\title{
Identification and Biological Activities of Bryostatins from Japanese Bryozoan
}

\author{
Sayo Ueno, ${ }^{1}$ Ryo C. Yanagita,,${ }^{2}$ Kazuma Murakami, ${ }^{1}$ Akira Murakami, ${ }^{1}$ Harukuni Tokuda, ${ }^{3}$ \\ Nobutaka SuzuKI, ${ }^{3}$ Takeshi FujIwARA, ${ }^{4}$ and Kazuhiro IRIE ${ }^{1, \dagger}$ \\ ${ }^{1}$ Department of Food Science and Biotechnology, Graduate School of Agriculture, Kyoto University, \\ Kyoto 606-8502, Japan \\ ${ }^{2}$ Department of Applied Biological Science, Faculty of Agriculture, Kagawa University, Kagawa 761-0795, Japan \\ ${ }^{3}$ Department of Complementary and Alternative Medicine Clinical R\&D, Graduate School of Medical Science, \\ Kanazawa University, Ishikawa 920-8640, Japan \\ ${ }^{4}$ OP-BIO Factory Co., Ltd., Okinawa 901-0152, Japan
}

Received January 16, 2012; Accepted February 6, 2012; Online Publication, May 7, 2012

[doi:10.1271/bbb.120026]

Six bryostatins were isolated from Japanese bryozoan by evaluating their binding to the $\mathrm{C} 1 \mathrm{~B}$ domain of protein kinase $\mathrm{C} \delta$ (PKC $\delta$ ). Structure-activity studies of bryostatins 4, 10, and 14 suggested that the ester group at $\mathrm{C20}$ was not necessary for binding to and activating PKC $\delta$. These bryostatins showed significant anti-tumorpromoting activity in induction tests with the EpsteinBarr virus early antigen.

Key words: protein kinase C; bryostatin; Bugula neritina; tumor promotion; Epstein-Barr virus

Protein kinase $\mathrm{C}$ (PKC) isozymes play a crucial role in cellular signal transduction via second-messenger diacylglycerols. ${ }^{1)}$ Protein kinase $\mathrm{C} \delta(\mathrm{PKC} \delta)$, one of the PKC isozymes, is involved in tumor suppression and apoptosis.,3) Bryostatin 1 (bryo-1, Fig. 1), which was isolated from the marine bryozoan, Bugula neritina, ${ }^{4)}$ showed strong anti-cancer and anti-tumor-promoting activity through $\mathrm{PKC} \delta$-dependent mechanisms. ${ }^{5,6)}$ Bryo1 has also attracted strong attention as a therapeutic lead against Alzheimer's disease and acquired immune deficiency syndrome. ${ }^{7)}$ Although 20 bryostatin homologues have been identified, ${ }^{6,8,9)}$ their limited availability from nature has hampered studies of their structureactivity relationships and molecular mechanisms of action. It is necessary to develop a convenient and reliable way to identify bryostatins and bryostatin-like compounds with high sensitivity and selectivity.

Bryo- 1 binds to the cysteine-rich $\mathrm{C} 1$ domains of $\mathrm{PKC}$ isozymes (C1A and $\mathrm{C} 1 \mathrm{~B})$ for their activation. ${ }^{1)}$ Since whole PKC isozymes are highly unstable and precious, our group has developed a synthetic $\mathrm{C} 1$ peptide library that binds to PKC activators with an affinity comparable to that of whole PKC isozymes. ${ }^{10,11)}$ We screened in this present study for $\mathrm{PKC} \delta$ ligands in marine organisms by evaluating their binding to a $\mathrm{C} 1 \mathrm{~B}$ peptide of $\mathrm{PKC} \delta$ $(\delta$-C1B) based on competition with the potent PKC activator, $\left[{ }^{3} \mathrm{H}\right]$ phorbol 12,13-dibutyrate (PDBu, PerkinElmer Japan, Yokohama, Japan).

Among over $200 \mathrm{CHCl}_{3} / \mathrm{MeOH}$ extracts of marine organisms (sponges, cyanobacteria, and bryozoan) col-

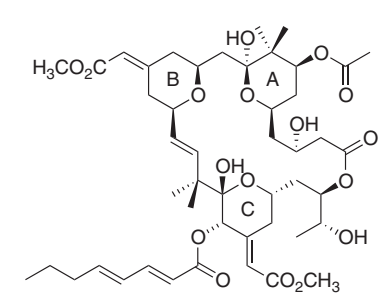

Bryostatin 1 (Bryo-1)

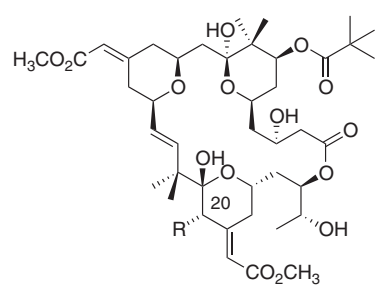

Bryostatin 4: $\mathrm{R}=\mathrm{OCO}\left(\mathrm{CH}_{2}\right)_{3} \mathrm{CH}_{3}$ Bryostatin $5: \mathrm{R}=\mathrm{OCOCH}_{3}$ Bryostatin $10: \mathrm{R}=\mathrm{H}$ Bryostatin $14: \mathrm{R}=\mathrm{OH}$

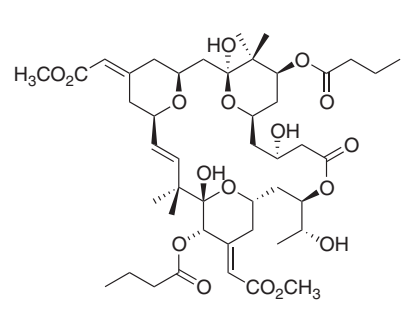

Bryostatin 8

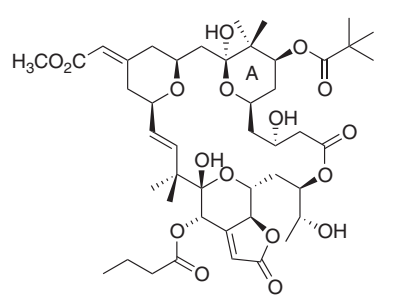

Bryostatin 19
Fig. 1. Structure of Bryostatins.

The FAB-MS data (Jeol JMS-600, $m$-nitrobenzyl alcohol as a matrix, except glycerol for bryo- 8 and bryo-10) for the compounds isolated in this study are as follows: bryo-4, $m / z$ $917[\mathrm{M}+\mathrm{Na}]^{+}$; bryo-5, $m / z 889[\mathrm{M}+\mathrm{Na}]^{+}$; bryo-8: $m / z 863[\mathrm{MH}-18]^{+}, 845$ $\left.[\mathrm{MH}-36]^{+}, 827[\mathrm{MH}-54]^{+}\right)$; bryo-10, $m / z 831[\mathrm{M}+\mathrm{Na}]^{+}$; bryo- $14, m / z 831[\mathrm{M}+\mathrm{Li}]^{+}$in the presence of LiI; bryo-19, $m / z$ $879[\mathrm{MH}]^{+}$.

lected by the OP-BIO Factory Co. (Okinawa), several extracts of $B$. neritina exhibited high affinity for $\delta$-C1B. This bryozoan found in the Gulf of Imazu (Fukuoka, Japan) was harvested in the summer of 2010. Extraction of the animal ( $6 \mathrm{~kg}$ wet weight) was carried out twice with $\mathrm{CHCl}_{3} / \mathrm{MeOH}$ (1:1). The extract after evaporation was partitioned three times between EtOAc and water. The resulting EtOAc extract (26.5 g) was chromatographed on Wakogel C-200 (silica gel, Wako Pure Chemical Industries, Osaka, Japan), sequentially eluting with $100 \% \mathrm{CHCl}_{3}, 30 \%$ EtOAc in hexane, $100 \%$ EtOAc, and $100 \% \mathrm{MeOH}$, to give two active fractions from the $100 \% \mathrm{EtOAc}$ and $\mathrm{MeOH}$ eluates. These were purified again on the same silica gel with $i$-PrOH-

$\dagger$ To whom correspondence should be addressed. Tel: +81-75-753-6281; Fax: +81-75-753-6284; E-mail: irie@kais.kyoto-u.ac.jp Abbreviations: Bryo, bryostatin; EBV-EA, Epstein-Barr virus early antigen; PDBu, phorbol 12,13-dibutyrate; PKC, protein kinase C; TPA, 12-Otetradecanoylphorbol 13-acetate 
Table 1. $K_{\mathrm{i}}$ Values for the Inhibition of $\left[{ }^{3} \mathrm{H}\right] \mathrm{PDBu}$ Binding by Bryostatins

\begin{tabular}{cccc}
\hline \hline \multirow{2}{*}{$\begin{array}{c}\text { PKC } \delta \text { and its } \\
\text { C1 peptides }\end{array}$} & Bryo-4 & Bryo-10 & Bryo-14 \\
\cline { 2 - 4 } & 0.16 & 0.24 & 1.2 \\
Whole PKC $\delta$ & 5.2 & 6.6 & 42 \\
$\delta$-C1A & 0.17 & 0.15 & 0.45 \\
$\delta$-C1B & & & \\
\hline
\end{tabular}

$\mathrm{CHCl}_{3}$-hexane (2:20:78, 4:20:76, and 6:20:74) to yield two active fractions from the $4 \%$ and $6 \% i$-PrOH$\mathrm{CHCl}_{3}$-hexane eluates. These were further purified by column chromatography on YMC AA12S50 gel (ODS, Yamamura Chemical Laboratory, Kyoto, Japan) by using 90\% MeOH. HPLC with silica-gel and ODS-gel columns (YMC-packed SIL-SL12S05 and ODSAM12S05), respectively eluting with $i$ - $\mathrm{PrOH}-\mathrm{CHCl}_{3}-$ hexane $(5: 15: 80)$ and $80 \%$ acetonitrile in water and guided by the $\left[{ }^{3} \mathrm{H}\right] \mathrm{PDBu}$ inhibition assay with $\delta$-C1B, finally yielded bryo- $\left.4^{12}\right)(1.2 \mathrm{mg})$, bryo- $5^{13)}(0.3 \mathrm{mg})$, bryo- $8^{14)} \quad(0.5 \mathrm{mg})$, bryo- $\left.10^{15}\right)(2.3 \mathrm{mg})$, bryo- $14^{16)}$ $(0.9 \mathrm{mg})$, and bryo- $19^{8)}(0.3 \mathrm{mg})$. These compounds completely inhibited the specific binding of $\left[{ }^{3} \mathrm{H}\right] \mathrm{PDBu}$ at $1 \mu \mathrm{g} / \mathrm{mL}$. The ${ }^{1} \mathrm{H}$ - and ${ }^{13} \mathrm{C}-\mathrm{NMR}$ data (AVANCE III 500, Bruker, Germany; ref. tetramethylsilane, $296 \mathrm{~K}$ ), optical rotation (P-2200, Jasco, Tokyo, Japan), and FAB-MS (Jeol JMS-600, Tokyo, Japan) for these bryostatins were identical to those previously reported. Although Kamano et al. have identified bryo-4, 5, 6, 8, 9, and 10 from the Japanese bryozoan in the Gulf of Aomori, Ohzuchi and Sagami, ${ }^{15,17,18)}$ bryo-14 and 19 were alternatively identified in this study. Bryo- 1 , the major component of the American bryozoan, ${ }^{4)}$ could not be found at all in this sample. These results suggest that the geographical difference of $B$. neritina could affect the variability of the types and amounts of bryostatin homologues.

Bryo-4, 5, 10, and 14 all had a pivaloyl group on the A-ring, but had different substituents at C20 of the C-ring (Fig. 1). Little is known about the role of these substituents in the biological activities of bryostatins. Wender's group ${ }^{19)}$ have synthesized a simplified analogue of bryo- 1 with several ester substituents at C20, and suggested a correlation between the number of carbons on the $\mathrm{C} 20$ ester and the affinity for a mixture of rat PKC isozymes. However, the role of the ester and hydroxyl groups at $\mathrm{C} 20$ in the various biological activities of bryostatins has remained elusive. We therefore examined the biological activities of bryo-4, -10 , and -14 . The biological evaluation of bryo-5 was almost impossible because of its small amount.

Since the unique biological properties of bryo- 1 are considered to be correlated with the activation of $\mathrm{PKC} \delta,{ }^{20)}$ we evaluated the ability to bind to and activate $\mathrm{PKC} \delta$ by using our PKC $\delta \mathrm{C} 1$ peptides ${ }^{10,11)}$ and human recombinant $\mathrm{PKC} \delta$ (Pan Vera LLC, Madison, USA). The $50 \%$ inhibition value $\left(\mathrm{IC}_{50}\right)$ for the specific binding of $\left[{ }^{3} \mathrm{H}\right] \mathrm{PDBu}$ to $\mathrm{PKC} \delta$ was measured as previously reported. ${ }^{10,11)}$ The affinity of bryostatins for $\mathrm{PKC} \delta$ is expressed by the $K_{\mathrm{i}}$ value calculated from the $\mathrm{IC}_{50}$ and $K_{\mathrm{d}}$ values of $\left[{ }^{3} \mathrm{H}\right] \mathrm{PDBu}$ reported by Sharkey and Blumberg. ${ }^{21)}$ Table 1 shows that the $K_{\mathrm{i}}$ values of bryo4 and 10 for whole $\mathrm{PKC} \delta$ were almost equal to each
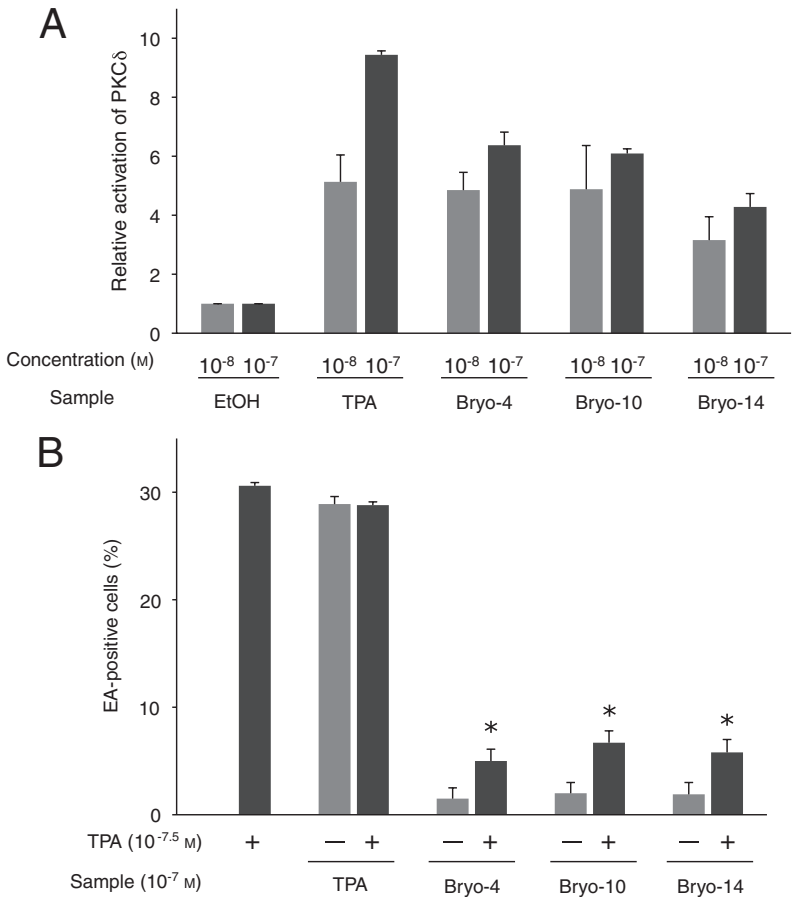

Fig. 2. Activation of $\mathrm{PKC} \delta$ and Induction of EBV-EA by Bryostatins.

A, Kinase activity of $\mathrm{PKC} \delta$ stimulated by bryostatins at the indicated concentrations. The values are expressed as a percentage relative to the control (EtOH). The final concentration of EtOH was $2.0 \%$. The results are presented as the average of duplicated points when all compounds were simultaneously tested. Error bars represent the standard error of the mean $(n=2)$. Another experiment gave similar results. B, Induction of EBV-EA by bryostatins. The percentages of EA-positive cells are shown. Each point is presented as the mean of triplicate experiments. Sodium $n$-butyrate (4 mM) was added to all samples to enhance the sensitivity of the Raji cells (B-lymphocytes). Only $0.1 \%$ EA-induction was observed at $4 \mathrm{~mm}$ sodium $n$-butyrate. The final concentration of dimethyl sulfoxide was $0.4 \%$. Error bars represent the standard error of the mean $(n=3) .{ }^{*}$ The difference between each sample and the positive control (TPA $\left.3.16 \times 10^{-8} \mathrm{M}\right)$ is statistically significant $(p<0.01$, $t$-test).

other and comparable to those of $\delta$-C1B. Both compounds bound significantly to $\delta$-C1A as reported for bryo- 1 ( $K_{\mathrm{i}}$ for $\delta$-C1A and $\delta$-C1B, 5.3 and $0.60 \mathrm{nM}$ ) unlike tumor promoters. ${ }^{22)}$ This suggests that the structural difference in the $\mathrm{C} 20$ side chain between bryo- 1 and bryo- 4 hardly changed the ability to bind to $\mathrm{PKC} \delta \mathrm{C} 1$ peptides. In contrast, the $K_{\mathrm{i}}$ values of bryo-14 for whole PKC $\delta$ and its $\mathrm{C} 1$ peptides were about 8 times larger than those of bryo- 4 and 10 , possibly due to the hydroxyl group at $\mathrm{C} 20$. These results indicate that the hydrophobicity at $\mathrm{C} 20$ slightly influenced the binding to $\mathrm{PKC} \delta$, but that the $\mathrm{C} 20$ ester group did not increase the binding ability. This conclusion is in contrast with that obtained when using the C20 esters of Wender's simplified analogue of bryo- $1 ;{ }^{19)}$ the hydrophobic C20 ester was necessary to potently bind to rat PKC isozymes in Wender's analogues.

To evaluate the ability of these bryostatins to activate $\operatorname{PKC} \delta$, the phosphorylation levels were measured by using a fluorescence-labeled peptide substrate (PepTag ${ }^{\circledR}$ non-radioactive protein kinase assay; Promega, Tokyo, Japan) according to the manufacturer's instructions (Fig. 2A). After the reaction had been stopped by heating at $95^{\circ} \mathrm{C}$ for $10 \mathrm{~min}$, the samples were loaded on to $0.8 \%$ agarose gel (Nippon Gene, Toyama, Japan) 
which was then quantified by densitometry software (NIH ImageJ, Bethesda, MD, USA). Bryo-4 and -10 both activated $\mathrm{PKC} \delta$ even at $1.0 \times 10^{-8} \mathrm{M}$, comparable to 12-O-tetradecanoylphorbol 13 -acetate (TPA) as a positive control, while bryo-14 showed slightly weaker activation. These activation profiles are in good agreement with the results of the binding assay (Table 1).

Anti-tumor-promoting activity is characteristic of bryo- $1^{23)}$ while most PKC activators in nature are tumor promoters. The anti-tumor-promoting activity was evaluated in vitro, based on the inhibitory activity of the Epstein-Barr virus early antigen (EBV-EA) induced by TPA. ${ }^{24,25)}$ EBV is activated by treating with a tumor promoter like TPA to generate EA which can then be detected by an indirect immunofluorescence technique. Figure 2B shows that TPA generated about $30 \%$ of EA-positive cells at $3.16 \times 10^{-8} \mathrm{M}$. In contrast, bryo-4, -10 , and -14 showed almost no induction $\left(1.0 \times 10^{-7} \mathrm{M}\right)$, even at $1.0 \times 10^{-6} \mathrm{M}$ (data not shown), and significantly attenuated the induction by TPA $\left(3.16 \times 10^{-8} \mathrm{M}\right)$. Quite similar results have been reported for bryo-1. ${ }^{23)}$ These results suggest that bryo- $4,-10$, and -14 had little tumorpromoting activity and that the inhibitory activity of EBV-EA was not related to the structure at C20. This was consistent with the finding that 20-epi-bryo-7, with an acetyloxy group at C20, exhibited significant biological activity in antiproliferative assays against several cancer cell lines. ${ }^{26)}$ These data do not reflect well the difference in the binding affinity to $\operatorname{PKC} \delta$, possibly because these data were measured at a higher concentration $\left(1.0 \times 10^{-7} \mathrm{M}\right)$ when compared with the $K_{\mathrm{i}}$ values for $\operatorname{PKC} \delta\left(1.0 \times 10^{-9} \mathrm{M}\right)$.

In summary, we screened and identified six bryostatins from the Japanese bryozoan by using a $\left[{ }^{3} \mathrm{H}\right] \mathrm{PDBu}$ binding assay with the $\mathrm{PKC} \delta$ - $\mathrm{C} 1 \mathrm{~B}$ peptide developed by us. Structure-activity studies on bryo-4, -10 , and -14 clearly indicated that the $\mathrm{C} 20$ ester was not necessary for binding to and activating $\mathrm{PKC} \delta$, nor for the anti-tumorpromoting activity of bryostatins. As Wender has suggested, ${ }^{19,27)}$ this means that one can utilize this position to introduce a photoaffinity label or a linker to identify new targets other than PKC isozymes. Since bryostatins are not tumor promoters, conventional assays for PKC ligands such as EBV-EA induction are not applicable. The assay presented in this paper would be useful for finding new PKC ligands with antagonistic activities like bryostatins.

\section{Acknowledgments}

This research was partly supported by the Challenging Exploratory Research program (no. 23658100) to K.I. and R.C.Y. from The Ministry of Education, Culture, Sports, Science and Technology of Japan.

\section{References}

1) Nishizuka Y, FASEB J., 9, 484-496 (1995).

2) Lu Z, Hornia A, Jiang Y-W, Zang Q, Ohno S, and Foster DA, Mol. Cell. Biol., 17, 3418-3428 (1997).

3) Jackson DN and Foster DA, FASEB J., 18, 627-636 (2004).

4) Pettit GR, Herald CL, Doubek DL, Herald DL, Arnold E, and Clardy J, J. Am. Chem. Soc., 104, 6846-6848 (1982).

5) Bögi K, Lorenzo P, Szállási Z, Ács P, Wagner G, and Blumberg PM, Cancer Res., 58, 1423-1428 (1998).

6) Mutter R and Wills M, Bioorg. Med. Chem., 8, 1841-1860 (2000).

7) Mackay HJ and Twelves CJ, Nat. Rev. Cancer, 7, 554-562 (2007).

8) Lin H, Yi Y, Li W, Yao X, and Wu H, Zhongguo Haiyang Yaowu, 17, 1-3 (1998).

9) Lopanik N, Gustafson KR, and Lindquist N, J. Nat. Prod., 67, 1412-1414 (2004).

10) Irie $K$, Oie $K$, Nakahara $A$, Yanai $Y$, Ohigashi $H$, Wender PA, Fukuda H, Konishi H, and Kikkawa U, J. Am. Chem. Soc., 120, 9159-9167 (1998).

11) Shindo M, Irie K, Nakahara A, Ohigashi H, Konishi H, Kikkawa U, Fukuda H, and Wender PA, Bioorg. Med. Chem., 9, 20732081 (2001).

12) Pettit GR, Kamano Y, Herald CL, and Tozawa M, J. Am. Chem. Soc., 106, 6768-6771 (1984).

13) Pettit GR, Kamano Y, Herald CL, and Tozawa M, Can. J. Chem., 63, 1204-1208 (1985).

14) Pettit GR, Kamano Y, Aoyagi R, Herald CL, Doubek DL, Schmidt JM, and Rudloe JJ, Tetrahedron, 41, 985-994 (1985).

15) Kamano $\mathrm{Y}$, Zhang HP, Morita H, Itokawa H, Shirota O, Pettit GR, Herald DL, and Herald CL, Tetrahedron, 52, 2369-2376 (1996).

16) Pettit GR, Gao F, Sengupta D, Coll JC, Herald CL, Doubek DL, Schmidt JM, van Camp JR, Rudloe JJ, and Nieman RA, Tetrahedron, 47, 3601-3610 (1991).

17) Kamano Y, Zhang HP, Hino A, Yoshida M, Pettit GR, Herald CL, and Itokawa H, J. Nat. Prod., 58, 1868-1875 (1995).

18) Pettit GR, Gao F, Blumberg PM, Herald CL, Coll JC, Kamano Y, Lewin NE, Schmidt JM, and Chapuis JC, J. Nat. Prod., 59, 286-289 (1996).

19) Wender PA and Hinkle KW, Tetrahedron Lett., 41, 6725-6729 (2000).

20) Lorenzo PS, Bögi K, Hughes KM, Beheshti M, Bhattacharyya D, Garfield SH, Pettit GR, and Blumberg PM, Cancer Res., 59, 6137-6144 (1999).

21) Sharkey NA and Blumberg PM, Cancer Res., 45, 19-24 (1985).

22) Irie K, Nakagawa Y, and Ohigashi H, Curr. Pharm. Des., 10, 1371-1385 (2004).

23) Gschwendt M, Fürstenberger G, Rose-John S, Rogers M, Kittstein W, Pettit GR, Herald CL, and Marks F, Carcinogenesis, 9, 555-562 (1988).

24) zur Hausen H, Bornkamm GW, Schmidt R, and Hecker E, Proc. Natl. Acad. Sci. USA, 76, 782-785 (1979).

25) Irie K, Okuno $S$, Koshimizu $K$, Tokuda $H$, Nishino $H$, and Iwashima A, Int. J. Cancer, 43, 513-519 (1988).

26) Trost BM and Dong G, J. Am. Chem. Soc., 132, 16404-16416 (2010).

27) Wender PA and Baryza JL, Org. Lett., 7, 1177-1180 (2005). 